\title{
Data report: carbon isotope composition of total dissolved inorganic carbon in interstitial water, Sites U1316, U1317, and U1318, Porcupine Seabight ${ }^{1}$
}

\author{
Tracy D. Frank ${ }^{2}$
}

\section{Chapter contents}

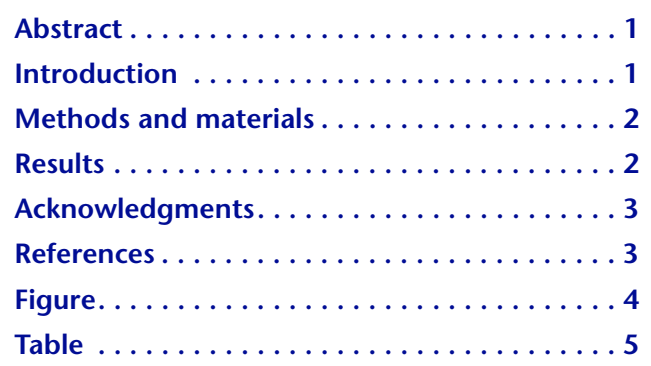

${ }^{1}$ Frank, T.D., 2009. Data report: carbon isotope composition of total dissolved inorganic carbon in interstitial water, Sites U1316, U1317, and U1318, Porcupine Seabight. In Ferdelman, T.G., Kano, A., Williams, T., Henriet, J.-P., and the Expedition 307 Scientists, Proc. IODP, 307: Washington, DC (Integrated Ocean Drilling Program Management International, Inc.).

doi:10.2204/iodp.proc.307.206.2009

${ }^{2}$ Department of Geosciences, 214 Bessey Hall, University of Nebraska-Lincoln, Lincoln NE 685880340, USA. tfrank2@unl.edu

\begin{abstract}
The carbon isotope composition of total dissolved inorganic carbon (DIC) was measured on 111 samples of interstitial water from Sites U1316-U1318 drilled during Integrated Ocean Drilling Program Expedition 307 to the Porcupine Seabight, southwest of Ireland. The analyses were performed to aid in understanding processes involved in the origin and development of Challenger Mound, a deepwater coral mound that was the focus of the expedition. Site U1317 was drilled into the northwest shoulder of Challenger Mound, whereas Sites U1316 and U1318 penetrated siliciclastic slope facies that accumulated downslope and upslope of the mound, respectively. The $\delta^{13} \mathrm{C}_{\mathrm{DIC}}$ values in interstitial water range from $-18.3 \%$ to $+3.9 \%$ Vienna Peedee belemnite. Maximum and minimum values occur in juxtaposition in the two deepest samples recovered from Site U1317 and correspond to a maximum in dissolved methane. At all three sites, downhole profiles of $\delta^{13} \mathrm{C}_{\mathrm{DIC}}$ values show a marked change in slope across a major unconformity between the middle Miocene and upper Pliocene series. At Site U1317, $\delta^{13} \mathrm{C}_{\mathrm{DIC}}$ values decrease from $-2.5 \%$ o to $-8.5 \%$ from the top of the core to the unconformity at $\sim 122$ meters below seafloor (mbsf). Below this depth, values increase overall to a maximum value of $+3.9 \%$. At Sites U1316 and U1318, the $\delta^{13} \mathrm{C}_{\mathrm{DIC}}$ values decrease markedly over the uppermost $10 \mathrm{~m}$ to values lower than $-15 \%$ before increasing with depth to approximately $-6 \%$ at the middle Miocene/upper Pliocene unconformity. Below the unconformity, $\delta^{13} \mathrm{C}_{\mathrm{DIC}}$ values increase with depth toward maxima ranging between $0 \%$ and $+1.5 \%$.
\end{abstract}

\section{Introduction}

This report provides the results of carbon isotopic analyses performed on total dissolved inorganic carbon (DIC) on 111 samples of interstitial water recovered from Integrated Ocean Drilling Program (IODP) Sites U1316-U1318 during Expedition 307 to the Porcupine Seabight. The seabight, located southwest of Ireland, is known for extensive development of deepwater coral mounds up to $160 \mathrm{~m}$ high that occur in water depths of 600-1000 $\mathrm{m}$ (Freiwald and Roberts, 2005). A major objective of IODP Expedition 307 was to investigate two competing hypotheses regarding the initiation and development of deepwater coral mounds: that mound development is (1) controlled by changes in ocean circulation and cli- 
mate (Mullins et al., 1981; Dorschel et al., 2005) and (2) related to the presence of light hydrocarbon seeps (Hovland et al., 1994, 1998). In this regard, the expedition focused on the origin and development of Challenger Mound $\left(52^{\circ} 23^{\prime} \mathrm{N}, 11^{\circ} 43^{\prime} \mathrm{W}\right)$, which lies at a water depth of $\sim 800 \mathrm{~m}$ in the Belgica mound province on the southwest-facing slope of Porcupine Seabight (see the "Expedition 307 summary" chapter).

Challenger Mound was penetrated five times during Expedition 307 (Holes U1317A-U1317E). Examinations of the resulting cores indicate that the mound developed atop a major unconformity between the middle Miocene and upper Pliocene that is also developed at nearby Sites U1316 and U1318 (see the "Expedition 307 summary" chapter; Kano et al., 2007). The stratigraphic section was divided into two distinct units on the basis of changes in lithology. The upper lithostratigraphic Unit 1, which records the initiation and growth of Challenger Mound, consists of silty coral floatstone and rudstone. These mound-related lithologies lie atop a sharp erosional contact with sandy, sometimes glauconitic, siltstone of Unit 2, which continues to the bottom of Holes U1317AU1317E. Sr isotopic, biostratigraphic, and magnetostratigraphic data indicate that Unit 1 formed during the last 2.6 m.y., whereas the underlying sandy siltstone (Unit 2) dates to the middle Miocene (Kano et al., 2007).

To better understand the context of mound development, two additional sites, Sites U1316 and U1318, were drilled through slope sediments that enclose Challenger Mound. Site U1316 was located upslope and Site U1318 downslope of Site U1317. The stratigraphic section at both sites was divided into three lithostratigraphic units (see the "Expedition 307 summary" chapter). At both sites, the uppermost lithostratigraphic Unit 1 consists of grayish brown silty clay with scattered pebbles interpreted by shipboard scientists as ice-rafted debris. At Site U1318, the underlying Unit 2 consists of interbedded silty clay and fine- to medium-grained sandstone with scattered pebbles. At Site U1316, Unit 2 consists of a thin (2-4 m thick) interval of silty coral floatstone interpreted on the basis of seismic data to reflect penetration of the upslope basal edge of a coral mound (see the "Site U1316" chapter). At both sites, Unit 2 unconformably overlies variably sandy and glauconitic siltstone defined as Unit 3. Seismic, stratigraphic, and biostratigraphic data show that Unit 3 at Sites U1316 and U1318 corresponds to Unit 2 at Site U1317. Units 1 and 2 at Sites U1316 and U1318 correspond to the timing of coral mound development at Site U1317 (see the "Expedition 307 summary" chapter).

Because of distinct differences in the carbon isotope compositions of skeletal carbonate, sedimentary or- ganic matter, and microbially or thermally derived methane (Arthur et al., 1983), the $\delta^{13} \mathrm{C}$ data provided in the present study will help to constrain the major diagenetic processes affecting Challenger Mound and surrounding sediments and thereby contribute to understanding controls on the genesis of these unique ecosystems. Results are summarized in Table T1 and Figure F1.

\section{Methods and materials}

Interstitial water samples were collected from wholeround sections ranging from 5 to $20 \mathrm{~cm}$ in length, which were cut on the catwalk, capped, and taken to the laboratory for immediate processing. In the laboratory, samples were extruded from the core liner and the outside $\sim 1 \mathrm{~cm}$ was removed to minimize the potential for contamination. Samples were cut in half to allow examination of the core interior, and any visible outsized clasts and fossil debris $>1 \mathrm{~cm}$ in diameter were removed. The samples were then placed in a titanium squeezer, which was modified after the standard stainless steel squeezer of Manheim and Sayles (1974). Interstitial water was passed through a prewashed Whatman number 1 filter fitted above a titanium screen, filtered through a $0.45 \mu \mathrm{m}$ Gelman polysulfone disposable filter, and subsequently extruded into a precleaned $(10 \% \mathrm{HCl}) 50 \mathrm{~mL}$ plastic syringe attached to the bottom of the squeezer assembly. Splits (1-2 mL) of samples were placed into clean glass vials with polyseal caps in preparation for analysis of $\delta^{13} \mathrm{C}_{\text {DIC }}$. Approximately $10 \mathrm{mg}$ of mercuric chloride $(\mathrm{HgCl})$ was added to each sample to prevent microbial growth. Samples were stored at $4^{\circ}-10^{\circ} \mathrm{C}$ until analysis. Isotopic analyses were performed at the Environmental Isotope Laboratory at the University of Arizona in Phoenix, Arizona (USA). Samples were analyzed using an automated headspace sampler (Finnigan GasBench) connected to a continuousflow gas-ratio mass spectrometer (Finnigan Delta PlusXL). Samples were acidified with concentrated phosphoric acid, and a minimum of 30 min was allowed for degassing of the water sample. Carbon isotope ratios are reported in parts per thousand (\%o) relative to the Vienna Peedee belemnite (VPDB) standard. Precision is $\pm 0.2 \%$, as monitored through multiple analyses of an in-house sodium bicarbonate standard solution that was calibrated against National Bureau of Standards (NBS)-18 and NBS-19.

\section{Results}

The $\delta^{13} \mathrm{C}_{\mathrm{DIC}}$ values range from $-18.3 \%$ to $+3.9 \%$ o VPDB (Table T1). At all three sites, the middle Miocene/upper Pliocene unconformity corresponds to 
an inflection in the slope of downcore profiles in $\delta^{13} C_{\text {DIC }}$ values (Fig. F1). At Site U1317, $\delta^{13} C_{D I C}$ values decrease from $-2.5 \%$ near the top of the core to $-8.5 \% 0$ to the unconformity at 148 meters below seafloor (mbsf) (base of lithostratigraphic Unit 1). Below this depth, values increase gradually downcore through Unit 2 to a maximum of $+3.9 \%$ at 257.80 mbsf. The overall trend through Unit 2 is interrupted by two outliers to lower values of $-13.8 \%$ at $207.80 \mathrm{mbsf}$ and $-18.5 \%$ at 266.01 mbsf. The maximum and minimum $\delta^{13} \mathrm{C}_{\mathrm{DIC}}$ values at this site occur in adjacent samples that represent the two deepest samples recovered from Site U1317. These extremes correspond to a dissolved methane concentration of $\sim 6500 \mu \mathrm{M}$, the highest concentration encountered during Expedition 307 (see the "Site U1317" chapter).

Downcore trends in $\delta^{13} \mathrm{C}_{\mathrm{DIC}}$ values are very similar at Sites U1316 and U1318 (Fig. F1). Within the upper $\sim 10 \mathrm{~m}$ of Unit $1, \delta^{13} \mathrm{C}_{\mathrm{DIC}}$ values decrease by $\sim 8 \%$ o to reach minimum values for these sites of $-15 \%$ or lower. Below this depth, $\delta^{13} \mathrm{C}_{\mathrm{DIC}}$ values increase to approximately $-6 \%$ at the middle Miocene/upper Pliocene unconformity (base of Unit 2), with the rate of change increasing with depth. In Unit $3, \delta^{13} C_{D I C}$ values increase with depth toward maxima of $+0.4 \%$ at Site U1316 and $+1.6 \%$ at Site U1318.

\section{Acknowledgments}

Samples and data were provided by the Integrated Ocean Drilling Program (IODP). Funds for isotopic analyses were provided by a grant to the author from JOI-USSAC, administered by U.S. Science Support Program administered by the Joint Oceanographic Institutes (now Ocean Leadership). David Dettman at the Environmental Isotope Laboratory, University of Arizona, oversaw isotopic analyses. I am grateful to the Expedition 307 shipboard participants for discussions and assistance with sample collection. Thanks also to P. Meister, whose review comments improved this manuscript.

\section{References}

Arthur, M.A., Anderson, T.F., Kaplan, I.R., Veizer, J., and Land, L.S., 1983. Stable Isotopes in Sedimentary Geology. SEPM Short Course 10.

Dorschel, B., Hebbeln, D., Rüggeberg, A., Dullo, W.-C., and Freiwald, A., 2005. Growth and erosion of a cold-water coral covered carbonate mound in the northeast Atlantic during the late Pleistocene and Holocene. Earth Planet. Sci. Lett., 233(1-2):33-44. doi:10.1016/ j.epsl.2005.01.035

Freiwald, A., and Roberts, J.M., (Eds.), 2005. Cold-Water Corals and Ecosystems: Berlin (Springer-Verlag). doi:10.1007/3-540-27673-4

Hovland, M., Croker, P.F., and Martin, M., 1994. Fault-associated seabed mounds (carbonate knolls?) off western Ireland and north-west Australia. Mar. Pet. Geol., 11(2):232-246. doi:10.1016/0264-8172(94)90099-X

Hovland, M., Mortensen, P.B., Brattegard, T., Strass, P., and Rokoengen, K., 1998. Ahermatypic coral banks off midNorway: evidence for a link with seepage of light hydrocarbons. Palaios, 13(2):189-200. doi:10.2307/3515489

Kano, A., Ferdelman, T.G., Williams, T., Henriet, J.-P., Ishikawa, T., Kawagoe, N., Takashima, C., Kakizaki, Y., Abe, K., Sakai, S., Browning, E.L., Li, X., and the Integrated Ocean Drilling Program Expedition 307 Scientists, 2007. Age constraints on the origin and growth history of a deep-water coral mound in the northeast Atlantic drilled during Integrated Ocean Drilling Program Expedition 307. Geology, 35(11):1051-1054. doi:10.1130/G23917A.1

Manheim, F.T., and Sayles, F.L., 1974. Composition and origin of interstitial waters of marine sediments, based on deep sea drill cores. In Goldberg, E.D. (Ed.), The Sea (Vol. 5): Marine Chemistry: The Sedimentary Cycle: New York (Wiley), 527-568.

Mullins, H.T., Newton, C.R., Heath, K., and van Buren, H.M., 1981. Modern deep-water coral mounds north of Little Bahama Bank: criteria for recognition of deepwater coral bioherms in the rock record. J. Sediment. Petrol., 51:999-1013.

Initial receipt: 17 June 2008

Acceptance: 15 April 2009

Publication: 12 June 2009

MS 307-206 
Figure F1. Downcore trends in the carbon isotope composition of total dissolved inorganic carbon $\left(\delta^{13} \mathrm{C}_{\mathrm{DIC}}\right)$ in interstitial water, Sites U1316, U1317, and U1318. Also indicated are boundaries of major lithostratigraphic units and the depth of the middle Miocene/upper Pliocene unconformity (wavy unit boundaries). VPDB = Vienna Peedee belemnite.
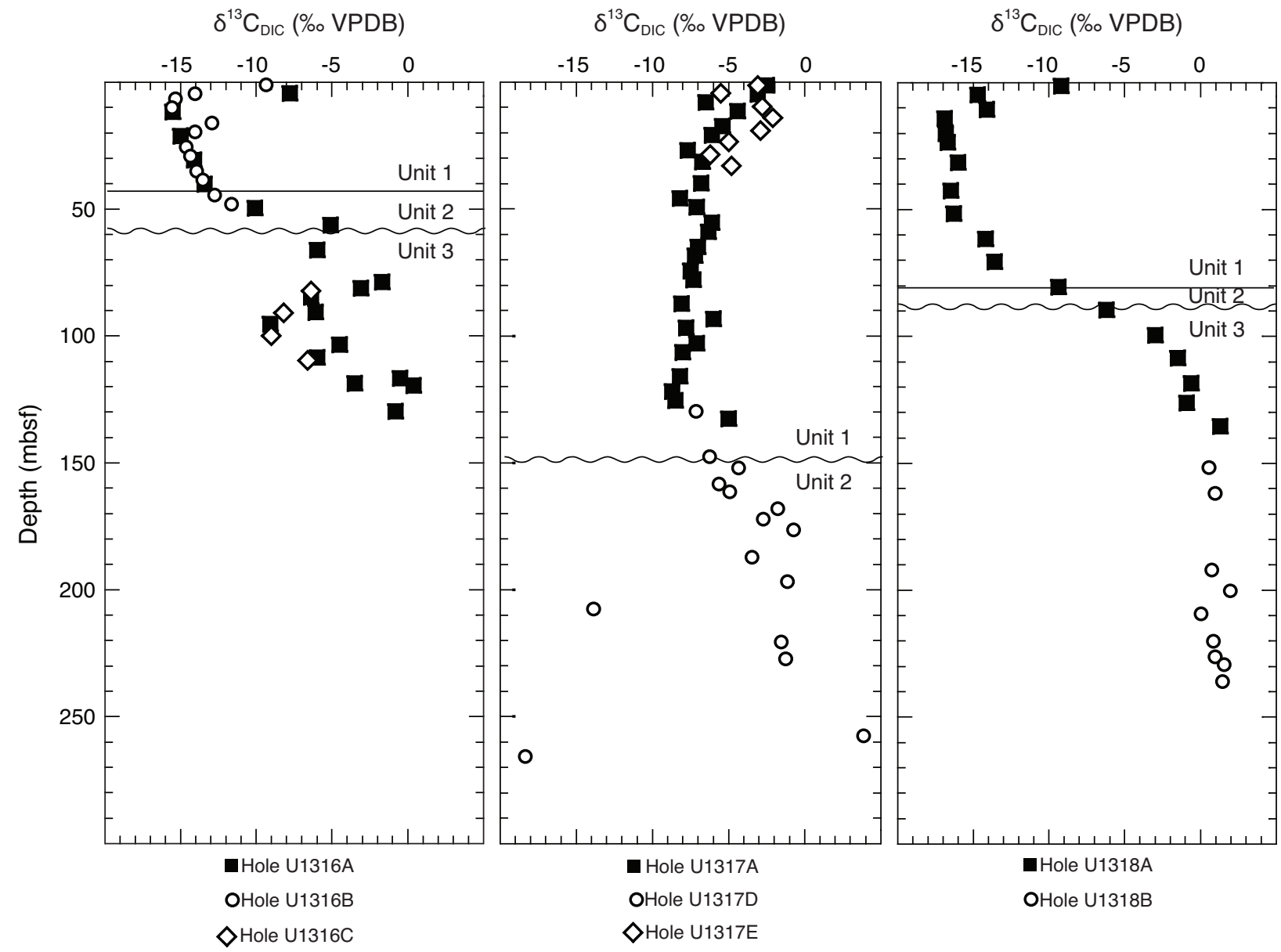
Table T1. Carbon isotope composition of total DIC in interstitial water, Sites U1316, U1317, and U1318. (See table note.)

\begin{tabular}{|c|c|c|}
\hline $\begin{array}{l}\text { Core, section, } \\
\text { interval }(\mathrm{cm})\end{array}$ & $\begin{array}{l}\text { Depth } \\
\text { (mbsf) }\end{array}$ & $\begin{array}{c}\delta^{13} \mathrm{C}_{\mathrm{DIC}} \\
(\% 0, \mathrm{VPDB})\end{array}$ \\
\hline \multicolumn{3}{|l|}{ 307-U1316A- } \\
\hline $1 \mathrm{H}-3,145-150$ & 4.45 & -7.8 \\
\hline $2 \mathrm{H}-3,140-150$ & 11.70 & -15.5 \\
\hline $3 \mathrm{H}-3,140-150$ & 21.20 & -15 \\
\hline $4 \mathrm{H}-3,140-150$ & 30.70 & -14.1 \\
\hline $5 \mathrm{H}-3,140-150$ & 40.20 & -13.4 \\
\hline $6 \mathrm{H}-3,140-150$ & 49.70 & -10.1 \\
\hline 7H-1, $140-150$ & 56.20 & -5.1 \\
\hline $8 \mathrm{H}-2,140-150$ & 66.29 & -6 \\
\hline $10 X-2,140-150$ & 78.70 & -1.7 \\
\hline $11 \mathrm{X}-2,140-150$ & 81.20 & -3.1 \\
\hline $12 X-1,140-150$ & 84.70 & -6.4 \\
\hline $13 X-2,140-150$ & 90.70 & -6.1 \\
\hline $15 X-1,112-117$ & 95.42 & -9.1 \\
\hline $16 X-3,140-150$ & 103.40 & -4.5 \\
\hline $17 X-1,7-17$ & 108.67 & -6 \\
\hline $18 X-3,140-150$ & 116.70 & -0.5 \\
\hline 19X-1, 39-49 & 118.69 & -3.5 \\
\hline $20 X-1,75-85$ & 119.55 & 0.4 \\
\hline $21 X-3,140-150$ & 129.70 & -0.8 \\
\hline \multicolumn{3}{|l|}{ 307-U1316B- } \\
\hline $1 \mathrm{H}-1,140-150$ & 1.40 & -9.3 \\
\hline $1 \mathrm{H}-3,190-200$ & 4.90 & -14 \\
\hline $2 \mathrm{H}-1,140-150$ & 6.90 & -15.3 \\
\hline $2 \mathrm{H}-3,190-200$ & 10.40 & -15.5 \\
\hline $3 \mathrm{H}-1,140-150$ & 16.40 & -12.9 \\
\hline $3 \mathrm{H}-3,190-200$ & 19.90 & -14 \\
\hline $4 \mathrm{H}-1,140-150$ & 25.90 & -14.6 \\
\hline $4 \mathrm{H}-3,190-200$ & 29.40 & -14.3 \\
\hline $5 \mathrm{H}-1,140-150$ & 35.40 & -13.9 \\
\hline $5 \mathrm{H}-3,190-200$ & 38.90 & -13.5 \\
\hline $6 \mathrm{H}-1,140-150$ & 44.90 & -12.7 \\
\hline $6 \mathrm{H}-3,190-200$ & 48.40 & -11.6 \\
\hline \multicolumn{3}{|l|}{ 307-U1316H-C- } \\
\hline $5 \mathrm{H}-3,135-150$ & 82.35 & -6.4 \\
\hline $6 \mathrm{H}-3,74-94$ & 90.90 & -8.2 \\
\hline $7 \mathrm{H}-2,130-150$ & 100.00 & -9 \\
\hline $8 \mathrm{H}-2,130-150$ & 109.70 & -6.6 \\
\hline \multicolumn{3}{|l|}{ 307-U1317A- } \\
\hline $1 \mathrm{H}-1,140-150$ & 1.40 & -2.5 \\
\hline $1 \mathrm{H}-3,190-200$ & 4.90 & -3.1 \\
\hline $2 \mathrm{H}-1,140-150$ & 7.90 & -6.5 \\
\hline $2 \mathrm{H}-3,190-200$ & 11.40 & -4.4 \\
\hline $3 \mathrm{H}-1,140-150$ & 17.40 & -5.4 \\
\hline $3 \mathrm{H}-3,190-200$ & 20.90 & -6.1 \\
\hline $4 \mathrm{H}-1,140-150$ & 26.90 & -7.7 \\
\hline $4 \mathrm{H}-4,140-150$ & 31.40 & -6.7 \\
\hline $5 \mathrm{H}-3,190-200$ & 39.90 & -6.8 \\
\hline $6 \mathrm{H}-1,140-150$ & 45.90 & -8.2 \\
\hline $6 \mathrm{H}-3,190-200$ & 49.40 & -7.1 \\
\hline $7 \mathrm{H}-1,140-150$ & 55.40 & -6.1 \\
\hline 7H-3, 190-200 & 58.90 & -6.3 \\
\hline $8 \mathrm{H}-1,140-150$ & 64.90 & -7 \\
\hline $8 \mathrm{H}-3,190-200$ & 68.40 & -7.2 \\
\hline $9 \mathrm{H}-1,140-150$ & 74.40 & -7.5 \\
\hline $9 \mathrm{H}-3,190-200$ & 77.90 & -7.3 \\
\hline $10 \mathrm{H}-3,190-200$ & 87.40 & -8.1 \\
\hline $11 \mathrm{H}-1,140-150$ & 93.40 & -6 \\
\hline $11 \mathrm{H}-3,190-200$ & 96.90 & -7.8 \\
\hline $12 \mathrm{H}-1,140-150$ & 102.90 & -7.1 \\
\hline $12 \mathrm{H}-3,190-200$ & 106.40 & -8 \\
\hline $13 \mathrm{H}-3,190-200$ & 115.90 & -8.2 \\
\hline
\end{tabular}

\begin{tabular}{|c|c|c|}
\hline $\begin{array}{l}\text { Core, section, } \\
\text { interval (cm) }\end{array}$ & $\begin{array}{l}\text { Depth } \\
\text { (mbsf) }\end{array}$ & $\begin{array}{c}\delta^{13} C_{D I C} \\
(\% o, \text { VPDB })\end{array}$ \\
\hline $14 \mathrm{H}-1,140-150$ & 121.90 & -8.7 \\
\hline $14 \mathrm{H}-3,190-200$ & 125.40 & -8.5 \\
\hline $17 X-1,190-200$ & 132.70 & -5 \\
\hline \multicolumn{3}{|l|}{ 307-U1317D- } \\
\hline $3 R-2,185-200$ & 129.95 & -7.1 \\
\hline $5 \mathrm{R}-1,198-213$ & 147.78 & -6.2 \\
\hline $6 \mathrm{R}-1,185-200$ & 152.25 & -4.3 \\
\hline 7R-2, 185-200 & 158.75 & -5.6 \\
\hline $7 R-4,135-150$ & 161.75 & -4.9 \\
\hline 8R-2, 182-197 & 168.42 & -1.7 \\
\hline $8 R-5,91-115$ & 172.48 & -2.7 \\
\hline $9 \mathrm{R}-1,185-200$ & 176.55 & -0.7 \\
\hline 10R-2, 124-145 & 187.54 & -3.4 \\
\hline $11 \mathrm{R}-2,180-200$ & 197.20 & -1.1 \\
\hline $12 \mathrm{R}-3,180-200$ & 207.80 & -13.8 \\
\hline $13 R-5,180-200$ & 220.90 & -1.5 \\
\hline $14 \mathrm{R}-3,180-200$ & 227.50 & -1.2 \\
\hline $17 R-4,130-150$ & 257.80 & 3.9 \\
\hline $18 R-3,180-200$ & 266.01 & -18.3 \\
\hline \multicolumn{3}{|l|}{ 307-U1317E- } \\
\hline $1 \mathrm{H}-1,140-150$ & 1.40 & -3.1 \\
\hline $1 \mathrm{H}-3,140-150$ & 4.40 & -5.5 \\
\hline $2 \mathrm{H}-2,140-150$ & 9.60 & -2.8 \\
\hline $2 \mathrm{H}-5,140-150$ & 14.10 & -2.1 \\
\hline $3 \mathrm{H}-2,140-150$ & 19.10 & -2.9 \\
\hline $3 \mathrm{H}-5,140-150$ & 23.60 & -5 \\
\hline $4 \mathrm{H}-2,140-150$ & 28.60 & -6.2 \\
\hline $4 \mathrm{H}-5,140-150$ & 33.10 & -4.8 \\
\hline \multicolumn{3}{|l|}{ 307-U1318A- } \\
\hline $1 \mathrm{H}-1,140-150$ & 1.40 & -9.2 \\
\hline $1 \mathrm{H}-3,190-200$ & 4.90 & -14.7 \\
\hline $2 \mathrm{H}-1,140-150$ & 10.60 & -14.1 \\
\hline $2 \mathrm{H}-3,190-200$ & 14.10 & -16.9 \\
\hline $3 \mathrm{H}-1,140-150$ & 20.10 & -16.8 \\
\hline $3 \mathrm{H}-3,190-200$ & 23.60 & -16.7 \\
\hline $4 \mathrm{H}-3,140-150$ & 31.45 & -16 \\
\hline $5 \mathrm{H}-3,190-200$ & 42.60 & -16.5 \\
\hline $6 \mathrm{H}-3,140-150$ & 51.60 & -16.3 \\
\hline 7H-3, 190-200 & 61.60 & -14.2 \\
\hline $8 \mathrm{H}-3,140-150$ & 70.57 & -13.6 \\
\hline $9 \mathrm{H}-3,190-200$ & 80.60 & -9.4 \\
\hline $10 \mathrm{H}-3,140-150$ & 89.60 & -6.2 \\
\hline $11 \mathrm{H}-3,190-200$ & 99.60 & -3 \\
\hline $12 \mathrm{H}-3,140-150$ & 108.60 & -1.5 \\
\hline $13 \mathrm{H}-3,190-200$ & 118.60 & -0.6 \\
\hline $14 \mathrm{H}-2,140-150$ & 126.10 & -0.9 \\
\hline $15 \mathrm{H}-2,135-150$ & 135.55 & 1.3 \\
\hline \multicolumn{3}{|l|}{ 307-U1318B- } \\
\hline $17 X-3,130-150$ & 152.00 & 0.6 \\
\hline $18 X-3,180-200$ & 162.10 & 1.0 \\
\hline $21 X-5,80-100$ & 192.40 & 0.8 \\
\hline $22 X-4,80-100$ & 200.50 & 2.0 \\
\hline $23 X-3,140-150$ & 209.60 & 0.1 \\
\hline $24 X-4,130-150$ & 220.50 & 0.9 \\
\hline $25 X-2,130-150$ & 226.50 & 1.0 \\
\hline $26 X-2,0-15$ & 229.81 & 1.6 \\
\hline $27 X-1,135-150$ & 236.35 & 1.5 \\
\hline
\end{tabular}

Note: DIC = dissolved inorganic carbon, VPDB = Vienna Peedee belemnite. 